archives-ouvertes

\title{
Trace metal elements as paleoenvironmental proxies: Why 2 should we account for sedimentation rate variations?
}

Vincent Crombez, Sebastien Rohais, Tristan Euzen, Laurent Riquier, François Baudin, Eider Hernandez-Bilbao

\section{To cite this version:}

Vincent Crombez, Sebastien Rohais, Tristan Euzen, Laurent Riquier, François Baudin, et al.. Trace metal elements as paleoenvironmental proxies: Why 2 should we account for sedimentation rate variations?. Environmental Modeling \& Assessment, Springer, 2020, 25 (5), pp.611-632. 10.1130/G47150.1 . hal-02955233

\section{HAL Id: hal-02955233 \\ https://hal-ifp.archives-ouvertes.fr/hal-02955233}

Submitted on 1 Oct 2020

HAL is a multi-disciplinary open access archive for the deposit and dissemination of scientific research documents, whether they are published or not. The documents may come from teaching and research institutions in France or abroad, or from public or private research centers.
L'archive ouverte pluridisciplinaire HAL, est destinée au dépôt et à la diffusion de documents scientifiques de niveau recherche, publiés ou non, émanant des établissements d'enseignement et de recherche français ou étrangers, des laboratoires publics ou privés. 
Publisher: GSA

Journal: GEOL: Geology

DOI:10.1130/G47150.1

1 Trace metal elements as paleoenvironmental proxies: Why

2 should we account for sedimentation rate variations?

3 Vincent Crombez ${ }^{1}$, Sebastien Rohais ${ }^{2}$, Tristan Euzen ${ }^{3}$, Laurent Riquier ${ }^{4}$, François

4 Baudin $^{4}$, and Eider Hernandez-Bilbao ${ }^{5}$

$5{ }^{1}$ Deep Earth Imaging Future Science Platform (DEI-FSP), Commonwealth Scientific and

6 Industrial Research Organisation (CSIRO), Kensington, WA 6151, Australia

$7 \quad{ }^{2}$ IFP Energies nouvelles, 92852 Rueil-Malmaison Cedex,

8 France

$9 \quad{ }^{3}$ IFP Technologies (Canada) Inc., Calgary, Alberta T2P 3T4, Canada

$10{ }^{4}$ Sorbonne Université, Centre National de la Recherche Scientifique, Institut des Sciences

11 de la Terre de Paris (ISTeP), 75005 Paris, France

$12{ }^{5}$ TOTAL, 64000 Pau, France

13 ABSTRACT

14 Trace metal elements (TMEs) are commonly used to reconstruct the

15 environmental conditions present during the deposition of organic-rich sediments. For

16 example, TME concentrations controlled by changes in primary productivity and redox

17 conditions are widely used in paleoenvironmental studies. Recently, these proxies have

18 undergone a resurgence of interest and are commonly used in large-scale (10-1000 km)

19 studies. However, applying these geochemical proxies at basin scale while ignoring

20 variations in sedimentation rates (SR) may lead to misinterpretation of

21 paleoenvironmental conditions. Here, we show how SR can affect the geochemical

22 records and may lead to incorrect interpretations of TME evolution. Accounting for SR, 
Publisher: GSA

Journal: GEOL: Geology

DOI:10.1130/G47150.1

23 we computed the authigenic fraction accumulation rates of key TMEs in the Upper

24 Montney and Doig Phosphate formations (Triassic, western Canada), and we correct the

25 concentration of these elements in the Vaca-Muerta Formation (Jurassic-Cretaceous,

26 Argentina). Our SR-corrected TME proxies require a different interpretation of

27 paleoenvironmental conditions (e.g., primary productivity, basin restriction) compared to

28 conventional TME results and highlight that elementary enrichments commonly

29 interpreted as indicative of anoxic depositional environments may reflect low SR and the

30 formation of condensed intervals. This work also introduces a new workflow to account

31 for SR in paleoenvironmental studies at basin scale and over long time periods.

\section{INTRODUCTION}

33 The recent development of shale plays requires an understanding of the

34 distribution of organic matter (OM) at both high resolution and basin scale. The OM

35 content in marine sedimentary records is mainly driven by three processes: organic

36 (primary) productivity, preservation of the OM (controlled by redox conditions and the

37 burial efficiency), and its dilution by nonorganic particles (Bohacs et al., 2005). In

38 practice, dilution rates of OM can be approached by using sedimentological and

39 stratigraphic techniques, whereas reconstruction of primary productivity and redox

40 dynamics is facilitated by geochemical proxies such as trace metal element (TME)

41 concentrations (Tribovillard et al., 2006). For instance, variations in U/Th ratios are

42 interpreted to reflect changes in oxygen concentration (Jones and Manning, 1994),

43 whereas variations in $\mathrm{Ba} / \mathrm{Al}$ ratios are thought to reflect the variation in primary

44 productivity (McManus et al., 1998). 
Publisher: GSA

Journal: GEOL: Geology

DOI:10.1130/G47150.1

To study the authigenic (or paleoenvironment-related) fraction of an element,

46 TME proxy analysis commonly includes: a normalization with immobile elements

47 (Calvert and Pedersen, 1993), and the computation of an enrichment factor using a

48 reference standard (Brumsack, 2006). Limitations of normalizations were presented by

49 Van Der Weijden (2002) and include the effects of low-denominator concentration (e.g.,

$50 \mathrm{Al}$ in carbonaceous rocks) and the spurious correlations that can result from

51 normalization to the same elements. Furthermore, many proxies have been defined in

52 case studies with limited vertical/stratigraphic scale (centimeter to decimeter), relatively

53 homogeneous sedimentary facies, and stable sedimentation rates (SRs; within the same

54 order of magnitude; e.g., Warning and Brumsack, 2000; Borchers et al., 2005, etc.).

55 However, it is widely accepted that SR can vary by several orders of magnitude within a

56 sedimentary basin, depending on the distance between the source and the depositional

57 environment.

58 Here, we used two organic-rich intervals with chronostratigraphic frameworks to

59 investigate the impact of SR variability on TME proxy interpretations. In western

60 Canada, the transition between the Lower Triassic Upper Montney Formation and the

61 Middle Triassic Doig Phosphate Zone is marked by a sudden drop in the SR - from 100

62 to $29 \mathrm{~m} / \mathrm{m} . \mathrm{y}$.—accompanied by a twofold increase in the OM

63 content. Based on TME concentrations, this OM increase was initially interpreted to

64 reflect a rise in primary productivity (Crombez et al., 2017a). However, subsequent,

65 regional process-based models of OM-rich sediment deposition suggested constant

66 primary productivity across the Upper Montney-Doig Phosphate boundary (Crombez et 
Publisher: GSA

Journal: GEOL: Geology

DOI:10.1130/G47150.1

67 al., 2017b). As a consequence, a first-order control of SR on OM abundance was favored

68 (Crombez et al., 2017b). This lack of consideration for the impact of SR is also present in

69 studies on the Vaca-Muerta Formation in Latin America, where several OM-rich intervals

70 associated with variable TME concentrations are present (e.g., Kietzmann et al., 2014;

71 Dominguez et al., 2016; Hernández Bilbao, 2016).

72 While numerous studies have addressed the dependency between the OM content

73 in shales and SR (e.g., Stein, 1990; Tyson, 2001; Burdige, 2007; Passey et al., 2010), the

74 impact of temporal variability of SR on paleoenvironmental proxies has been overlooked

75 (e.g., Lyons and Severmann, 2006; Little et al., 2015). In this contribution, we voluntary

76 used different TMEs from different case studies to show how TME concentrations are

77 affected by SR and suggest two workflows to evaluate paleoenvironmental changes.

78 Furthermore, we discuss the implication of the lack of SR integration in previous works

79 and the limitations of the proposed workflows.

80 DATA AND METHODS

81 The stratigraphic frameworks presented are based on Crombez et al. (2019) and

82 Euzen et al. (2018) for the Upper Montney and Doig Phosphate formations, and on

83 Sattler et al. (2016) for the Vaca-Muerta Formation. SR values were computed using an

84 estimated interval thickness and duration $\left(S S S S={ }^{\text {Thickness }}\right)$. Geochemical analyses were

Duration

85 conducted on samples from (1) a core transecting the Upper Montney and Doig

86 Phosphate formations (well 0/16-17-83-25W6; 67 samples) in

87 British Columbia, and (2) on cuttings from the Vaca-Muerta Formation (well Jaguel del

88 Rosauros X-1, 53 samples; and well Medano de la Mora X-

89 1, 77 samples; where the distance between both wells is 20 km) in 
Publisher: GSA

Journal: GEOL: Geology

DOI:10.1130/G47150.1

90 the Neuquén Basin. Element analyses on the Upper Montney and Doig Phosphate

91 formations were conducted by ACT Labs following their 4A-

92 4B protocol. Element analyses on the Vaca-Muerta Formation were conducted using a

93 handheld energy-dispersive X-ray fluorescence analyzer and processed following the

94 Rowe et al. (2012) method.

\section{AUTHIGENIC FRACTION ACCUMULATION RATE}

96 To illustrate the impact of SR on TME content across the Upper Montney and

97 Doig Phosphate formations (offshore to lower shoreface conditions; for sedimentologic

98 description, see Crombez et al., 2017a), we computed the authigenic fraction

99 accumulation rate (AFAR) of Mo and Ni using a high-resolution stratigraphic framework,

100 and we compared their evolution with conventional TME proxies. The computation of

101 the AFAR for an element $E$ (in $\mu \mathrm{g} / \mathrm{cm}^{2} / \mathrm{yr}$ ) requires the estimation of the SR (assuming a

102 constant sedimentation rate in an interval), bulk rock density ( $r$, defined here as the

103 Bouguer density), and the authigenic element concentration $E_{\text {Aut }}$ of a sample:

$105 \quad \mathrm{AFAR}_{E E}=\mathrm{EE}_{\text {Aut }} \mathrm{SR} \rho$.

106 Here, $E_{\text {Aut }}$ was determined using a detrital element $D$ by estimating a detrital $(E / D)_{\text {Source }}$

107 value (minimum acceptable value in the data set) from an $E$ versus $D$ cross-plot

108 (assuming a constant chemical nature in the sediment sources) and subtracting the detrital

109 fraction from the total $E$ concentration of each sample:

110

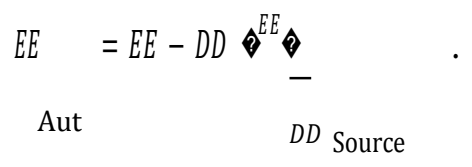

111 The SR drop across the Upper Montney-Doig Phosphate boundary is

112 accompanied by an increase in $\mathrm{Mo} / \mathrm{Al}$ and $\mathrm{Ni} / \mathrm{Al}$ ratios (Fig. 1A). In contrast, accounting

113 for SR variations resulted in no increase of the Mo and Ni AFAR. Here, the drop in 
Publisher: GSA

Journal: GEOL: Geology

DOI:10.1130/G47150.1

114 sediment supply across the boundary decreased the dilution of the authigenic fraction,

115 which resulted in elevated $\mathrm{Mo} / \mathrm{Al}$ and $\mathrm{Ni} / \mathrm{Al}$ ratios. It is therefore unlikely that these

116 increases were related to changes in paleoenvironmental condition.

117 A closer look at the AFAR showed significant variations in the proxies in the

118 Upper Montney Formation. In Figure 1A, the SR of the Upper Montney Formation is

119 considered constant; thus, the observed AFAR variations could be related to high-

120 frequency changes in SR and not to paleoenvironmental changes. To test this hypothesis,

121 we used a high-resolution stratigraphic framework (Euzen et al., 2018) highlighting high-

122 frequency SR variations (Fig. 1B). SR values vary from 50 to $75 \mathrm{~m} / \mathrm{m} . y$. in parasequences

123 UM1-UM5 and increase to 190-215 m/m.y. in UM6-UM7. The absolute values of the

124 AFAR are low in UM1-UM5 and high in the UM6-UM7 when compared to the AFAR

125 computed using the average Upper Montney Formation SR (Fig. 1A). However, the high-

126 frequency variations of the AFAR in UM1-UM5 and UM6-UM7 are not significantly

127 different (Fig. 1A versus Fig. 1B). The only significant difference occurs across the

128 UM5-UM6 boundary, where the average value of the AFAR increases. We interpret these

129 variations to be related to the amplitude of the change in SR. Across the UM5-UM6

130 boundary, the SR increases from 60 to $190 \mathrm{~m} / \mathrm{m} . \mathrm{y}$., which causes the significant increase

131 of the AFAR. Within UM1-UM5 and UM6-UM7, the units' average SR does not present

132 sufficient amplitude variation to affect the AFAR or the conventional TME proxies in a

133 way that could bias the interpretation. Based on these observations, we propose that

134 variations in SR of at least one order of magnitude are necessary to affect the

135 interpretation of conventional TME proxies.

136 CORRECTED ELEMENTARY CONCENTRATION 
Publisher: GSA

Journal: GEOL: Geology

DOI:10.1130/G47150.1

138 requires reference sedimentation rates $\left(S R_{\text {Ref }}\right)$ :

139

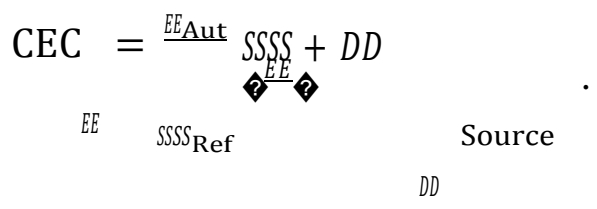

140 In the computation, $S R_{\text {Ref }}$ relates to the SR in other parts of the basin or to the SR

141 in other case studies The CEC shows what the elementary concentration should be if the

$142 S R$ were equal to $S R_{\text {Ref. }}$ This computation assumes $D>>E$, which implies that variations

143 of $E$ will only marginally affect $D$ (e.g., $D$ in \% and $E$ in ppm).

144 As in the Upper Montney and Doig Phosphate formations, the Vaca-Muerta

145 Formation shows varying SR. In the two investigated wells, located in the same

146 paleogeographic setting, the SR values vary from $24 \mathrm{~m} / \mathrm{m} . \mathrm{y}$. (in unit 1) to $90 \mathrm{~m} / \mathrm{m} . \mathrm{y}$. (in

147 unit 2) along well JDRx1 and from 16 m/m.y. (in unit 1) to $100 \mathrm{~m} / \mathrm{m} . \mathrm{y}$. (in unit 2) along

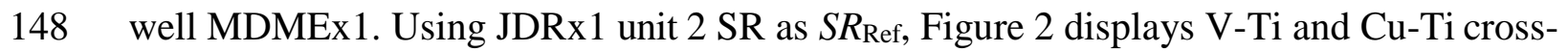

149 plots of two well intervals that intersect the basal units of the Vaca-Muerta Formation.

150 The uncorrected data plotted on Figure 2 suggest stronger authigenic enrichments in V

151 and $\mathrm{Cu}$, which are respectively related to redox conditions and primary productivity, in

152 unit 1, with V up to $300 \mathrm{ppm}$ and $\mathrm{Cu}$ up to $40 \mathrm{ppm}$. However, accounting for SR

153 differences between these units by computing the CEC highlights a weaker authigenic

154 enrichment signature in unit 1. Comparable to the Upper Montney and Doig Phosphate

155 formations, the conventional TME proxies are affected by SR in the Vaca-Muerta

156 Formation. Not accounting for SR, the TME records suggest an increase in bottom-water

157 oxygen levels associated with relatively constant primary productivity from unit 1 to unit

1582 (Calvert and Pedersen, 1993; Tribovillard et al., 2006). Accounting for SR by

159 calculating the CEC shows the opposite, i.e., decreasing bottom-water oxygen levels and 
Publisher: GSA

Journal: GEOL: Geology

DOI:10.1130/G47150.1

160 increasing primary productivity, in unit 2. In part of the Vaca-Muerta Formation, the

161 higher TME authigenic concentration is an artifact of a lower SR, which leads to the

162 concentration of the authigenic elements.

\section{IMPLICATION FOR PREVIOUS AND FUTURE STUDIES}

164 The influence of SR on TME content is summarized in Figure 3. In this

165 conceptual model, paleoenvironmental variations are assumed to control the TME

166 accumulation rates. It suggests that these variations and the SR will represent the two end

167 members on the control of the authigenic fractions. SR differences exceeding one order

168 of magnitude lead to a significant concentration (i.e., low SR) or dilution (i.e., high SR)

169 of the authigenic fraction of TMEs. In the latter case, normalizing to a detrital element

170 will only increase the effect of the SR. As the relative proportion of the detrital element

171 will increase in tandem with the increasing sediment supply, the ratio will decrease and

172 therefore show variations not caused by paleoenvironmental changes. This phenomenon

173 is illustrated by the vertical evolution of the ratios in Figure 3B, where: (1) the absolute

174 values of the ratios are different yet related to the same paleoenvironmental conditions,

175 and (2) the vertical evolution of the ratios are not representative of paleoenvironmental

176 changes, but instead they result from progradation of the sedimentary system and a

177 progressive increase in SR.

178 These observations have important implications for the use of TMEs as

179 paleoenvironmental proxies. The elemental ratios that characterize boundaries between

180 oxic, dysoxic, and anoxic conditions (e.g., Hatch and Leventhal, 1992; Jones and

181 Manning, 1994) vary depending on SR. In contrast, proxies that are based on ratios of

182 two authigenic components, for example, total organic carbon and Mo (a measure of 
Publisher: GSA

Journal: GEOL: Geology

DOI:10.1130/G47150.1

183 basin restriction; Algeo and Lyons, 2006) or Mo and U (a measure of anoxia; Algeo and

184 Tribovillard, 2009), should proportionately be affected by changes in SR, making them

185 more robust indicators of paleoenvironmental change as long as their concentrations

186 exceed those in the detrital fraction (i.e., by at least one order of magnitude).

187 When reconstructing large-scale paleoenvironmental conditions, it is important to

188 consider that the SR values were probably not the same. In studies where absolute

189 durations are not known, but where stratigraphic correlation suggests that sections

190 represent the same time interval, the authigenic fraction should be normalized to the

191 sedimentary thickness to approximately account for different dilutions.

192 It is important to acknowledge the limitations of calculated AFAR and CEC

193 values when studying paleoenvironmental conditions. The main limitations on the

194 interpretation of a TME proxy will also apply, as the studied element might be affected

195 by post- and syndepositional processes independent of the paleoenvironmental

196 conditions. In addition, a well-constrained SR quantification is required. Therefore, it is

197 important to acknowledge the uncertainties related to the compaction of the sediments. In

198 the computation of the AFAR, we recommend using a density representative of the

199 investigated interval compaction state (e.g., higher density for compacted strata and lower

200 density for uncompacted/recent sediments). For the computation of the CEC, if the

201 studied intervals are at the same compaction state, we recommend using the apparent SR

202 (i.e., computed using the compacted thickness); however, if the objective of the study is

203 to compare different sedimentary systems from different basins, we recommend

204 computing the uncompacted thickness of sedimentary strata (Fowler and Yang, 1998;

205 Bahr et al., 2001) to obtain comparable SR values. In addition, Enos (1991) presented a 
Publisher: GSA

Journal: GEOL: Geology

DOI:10.1130/G47150.1

206 wide range in SR variations across different sedimentary environments, and Droxler and

207 Schlager (1985) demonstrated high-frequency SR variations within one single

208 environment. Unfortunately, in ancient sediments, millimeter-scale SR values are not

209 accessible, and therefore best practice interpretation of the AFAR and the CEC should

210 focus on variation of the trends between units where SR values can be assumed to be

211 constant.

212 Last, the AFAR in UM7 (Fig. 1B) presents a "Christmas tree"

213 pattern. High AFAR values are often present above

214 parasequence set boundaries. These intervals are interpreted as flooding surfaces

215 followed by regression (Euzen et al., 2018) and are likely associated with low SR,

216 followed by increasing SR. The “Christmas tree” pattern is thus likely linked to the

217 progressive increase in SR during deposition of the parasequence, and the peaks in AFAR

218 are interpreted to relate to condensed intervals and concentration of TMEs with

219 associated OM.

220 CONCLUSION

221 To avoid misinterpretation of the geochemical record, we suggest calculating the

222 authigenic fraction accumulation rate or the corrected elementary concentration ofTMEs,

223 instead of using simple corrections such as elemental normalizations, enrichment factors,

224 or authigenic enrichments. These new proxies account for variations in SR and focus on

225 the temporal fluxes of authigenic elements rather than on their total concentration within

226 a sedimentary unit. With the increasing need to understand the high-resolution

227 distribution of OM, accounting for SR variations will improve the quantification of

228 temporal and spatial variations of anoxia and primary productivity. This will result in an 
Publisher: GSA

Journal: GEOL: Geology

DOI:10.1130/G47150.1

229 improved understanding of the controlling factors for OM accumulation and lead to better

230 predictions of the three-dimensional distribution of OM-rich intervals.

231 ACKNOWLEDGMENTS

232 Acknowledgments go to N. Vaisblat, for providing the geochemical data on the

233 Montney and Doig Phosphate formations; to the Mudrocks and Tight Oil

234 Characterization (MUDTOC) Consortium at the Colorado School of Mines (USA) for

235 funding the data collection on the Vaca-Muerta Formation; and to the Australian

236 Commonwealth Scientific and Industrial Research Organisation for supporting this

237 research. Special thanks to M. Kunzmann and C. Johnson for their comments on the

238 initial manuscript. P. Sansjofre, A. Riboulleau, and an anonymous reviewer are also

239 acknowledged for their helpful comments on the manuscript.

\section{REFERENCES CITED}

241 Algeo, T.J., and Lyons, T.W., 2006, Mo-total organic carbon covariation in modern

242 anoxic marine environments: Implications for analysis of paleoredox and

243 paleohydrographic conditions: Paleoceanography, v. 21, PA1016,

244 https://doi.org/10.1029/2004PA001112.

245 Algeo, T.J., and Tribovillard, N., 2009, Environmental analysis of paleoceanographic

246 systems based on molybdenum-uranium covariation: Chemical Geology, v. 268,

247 p. 211-225, https://doi.org/10.1016/j.chemgeo.2009.09.001.

248 Bahr, D.B., Hutton, E.W.H., Syvitski, J.P.M., and Pratson, L.F., 2001, Exponential

249 approximations to compacted sediment porosity profiles: Computers \& Geosciences,

250 v. 27, p. 691-700, https://doi.org/10.1016/S0098-3004(00)00140-0. 
Publisher: GSA

Journal: GEOL: Geology

DOI:10.1130/G47150.1

251 Bohacs, K.M., Carroll, A.R., Mankiewicz, P.J., Miskell-Gerhardt, K.J., Schwalbach,

252 J.O.N.R., Wegner, M.B., and Simo, J.A.T., 2005, Production, destruction, and

253 dilution — The many paths to source-rock development, in Harris, N.B., ed., The

254 Deposition of Organic-Carbon-Rich Sediments: Models, Mechanisms and

255 Consequences: Society for Sedimentary Geology (SEPM) Special Publication 82,p.

256 61-101, https://doi.org/10.2110/pec.05.82.0061.

257 Borchers, S.L., Schnetger, B., Böning, P., and Brumsack, H.J., 2005, Geochemical

258 signatures of the Namibian diatom belt: Perennial upwelling and intermittentanoxia:

259 Geochemistry Geophysics Geosystems, v. 6, Q06006,

$260 \quad$ https://doi.org/10.1029/2004GC000886.

261 Brumsack, H.-J., 2006, The trace metal content of recent organic carbon-rich sediments:

262 Implications for Cretaceous black shale formation: Palaeogeography,

263 Palaeoclimatology, Palaeoecology, v. 232, p. 344-361,

$264 \quad$ https://doi.org/10.1016/j.palaeo.2005.05.011.

265 Burdige, D.J., 2007, Preservation of organic matter in marine sediments: Controls,

266 mechanisms, and an imbalance in sediment organic carbon budgets?: Chemical

267 Reviews, v. 107, p. 467-485, https://doi.org/10.1021/cr050347q.

268 Calvert, S.E., and Pedersen, T.F., 1993, Geochemistry of Recent oxic and anoxic marine

269 sediments: Implications for the geological record: Marine Geology, v. 113, p. 67-88,

$270 \quad$ https://doi.org/10.1016/0025-3227(93)90150-T.

271 Crombez, V., Rohais, S., Baudin, F.,

272 and Euzen, T., 2016, Facies, well-log patterns, geometries and sequence stratigraphy

273 of a wave-dominated margin: Insight from the Montney Formation (Alberta, British 
Publisher: GSA

Journal: GEOL: Geology

DOI:10.1130/G47150.1

274 Columbia, Canada): Bulletin of Canadian Petroleum Geology, v. 64, p. 516-537,

275 https://doi.org/10.2113/gscpgbull.64.4.516.

276 Crombez, V., Baudin, F., Rohais, S., Riquier, L., Euzen, T., Pauthier, S., Ducros, M.,

277 Caron, B., and Vaisblat, N., 2017a, Basin scale distribution of organic matter in

278 marine fine-grained sedimentary rocks: Insight from sequence stratigraphy and

279 multi-proxies analysis in the Montney and Doig Formations: Marine and Petroleum

280 Geology, v. 83, p. 382-401, https://doi.org/10.1016/j.marpetgeo.2016.10.013.

281 Crombez, V., Rohais, S., Baudin, F., Chauveau, B., Euzen, T., and Granjeon, D., 2017b,

282 Controlling factors on source rock development: Implications from 3D stratigraphic

283 modeling of Triassic deposits in the Western Canada Sedimentary Basin: Bulletin de

284 la Société Géologique de France, v. 188, p. 30, https://doi.org/10.1051/bsgf/2017188.

285 Crombez, V., Rohais, S., Baudin, F., Euzen, T., Zonneveld, J.-P., and Power, M., 2019,

286 3D stratigraphic architecture, sedimentary budget, and sources of the Lower and

287 Middle Triassic strata of western Canada: Evidence for a major basin structural

288 reorganization: Petroleum Geoscience,

289 https://doi.org/10.1144/petgeo2019-024.

290 Dominguez, R.F., et al., 2016, Organic-

291 rich stratigraphic units in the Vaca Muerta formation, and their distribution and

292 characterization in the Neuquen Basin (Argentina), in SPE/AAPG/SEG

293 Unconventional Resources Technology Conference 2016,

295 https://doi.org/10.15530/urtec-2016-2456851. 
Publisher: GSA

Journal: GEOL: Geology

DOI:10.1130/G47150.1

296 Droxler, A.W., and Schlager, W., 1985, Glacial versus interglacial sedimentation rates

297 and turbidite frequency in the Bahamas: Geology, v. 13, p. 799-802, https://doi.org/10.1130/0091-7613(1985)13<799:GVISRA>2.0.CO;2.

299 Enos, P., 1991, Sedimentary parameters for computer modeling, in Franseen, E.K., ed., $300 \quad$ Sedimentary Modeling: Computer Simulations and Methods for Improved Parameter

301 Definition: Kansas Geological Survey Bulletin 233, p. 63-99.

302 Euzen, T., Moslow, T.F., Crombez, V., and Rohais, S., 2018, Regional stratigraphic

303 architecture of the Spathian deposits in western Canada-Implications for the

304 Montney Resource Play: Bulletin of Canadian Petroleum Geology, v. 66, p. 175-

305192.

306 Fowler, A.C., and Yang, X.S., 1998, Fast and slow compaction in sedimentary basins: SIAM Journal on Applied Mathematics, v. 59, p. 365-385, https://doi.org/10.1137/S0036139996287370.

309 Hatch, J.R., and Leventhal, J.S., 1992, Relationship between inferred redox potential of 310 the depositional environment and geochemistry of the Upper Pennsylvanian

311 (Missourian) Stark Shale Member of the Dennis Limestone, Wabaunsee County,

312 Kansas, U.S.A.: Chemical Geology, v. 99, p. 65-82, https://doi.org/10.1016/0009$313 \quad 2541(92) 90031-Y$

314 Hernández Bilbao, E., 2016, High-Resolution Chemostratigraphy, Sequence Stratigraphic

315 Correlation, Porosity and Fracture Characterization of the Vaca Muerta Formation, 316 Neuquén Basin, Argentina: Golden, Colorado, Colorado School of Mines, 221 p., 317 http://hdl.handle.net/11124/170104. 
Publisher: GSA

Journal: GEOL: Geology

DOI:10.1130/G47150.1

318 Jones, B., and Manning, D.A.C., 1994, Comparison of geochemical indices used for the

319 interpretation of palaeoredox conditions in ancient mudstones: Chemical Geology,

320 v. 111, p. 111-129, https://doi.org/10.1016/0009-2541(94)90085-X.

321 Kietzmann, D.A., Palma, R.M., Riccardi, A.C., Martín-Chivelet, J., and López-Gómez,

322 J., 2014, Sedimentology and sequence stratigraphy of a Tithonian-Valanginian

323 carbonate ramp (Vaca Muerta Formation): A misunderstood exceptional source rock

324 in the southern Mendoza area of the Neuquén Basin, Argentina: Sedimentary

325 Geology, v. 302, p. 64-86, https://doi.org/10.1016/j.sedgeo.2014.01.002.

326 Little, S.H., Vance, D., Lyons, T.W., and McManus, J., 2015, Controls on trace metal

327 authigenic enrichment in reducing sediments: Insights from modern oxygen-deficient

328 settings: American Journal of Science, v. 315, p. 77-119,

$329 \quad$ https://doi.org/10.2475/02.2015.01.

330 Lyons, T.W., and Severmann, S., 2006, A critical look at iron paleoredox proxies: New

331 insights from modern euxinic marine basins: Geochimica et Cosmochimica Acta, v.

332 70, p. 5698-5722, https://doi.org/10.1016/j.gca.2006.08.021.

333 McManus, J., et al., 1998, Geochemistry of barium in marine sediments: Implications for

334 its use as a paleoproxy: Geochimica et Cosmochimica Acta, v. 62, p. 3453-3473,

335 https://doi.org/10.1016/S0016-7037(98)00248-8.

336 Passey, Q.R., Bohacs, K., Esch, W.L., Klimentidis,

337 R., and Sinha, S., 2010, From oil-prone source rock to gas-producing shale

338 reservoir-Geologic and petrophysical characterization of unconventional shale gas 
Publisher: GSA

Journal: GEOL: Geology

DOI:10.1130/G47150.1

reservoirs, in International Oil and Gas Conference and Exhibition in China: Society

of Petroleum Engineers, https://doi.org/10.2118/131350-MS.

341 Rowe, H., Hughes, N., and Robinson, K., 2012, The quantification and application of

342 handheld energy-dispersive X-ray fluorescence (ED-XRF) in mudrock

343 chemostratigraphy and geochemistry: Chemical Geology, v. 324-235, p. 122-131,

345 https://doi.org/10.1016/j.chemgeo.2011.12.023.

346 Sattler, F., Dominguez, R.F., Fantín, M., Desjardins, P., Reijenstein, H., Benoit, S., Borgnia,

M., Vittore, F., Tomassini, F.G., and Feinstein, E., 2016, Anexo 1, in González, G., et al., eds., Transecta Regional de la Formación Vaca Muerta Integración de Sísmica,

349 Registros de Pozos, Coronas y Afloramientos.

350 Stein, R., 1990, Organic carbon content/sedimentation rate relationship and its

351 paleoenvironmental significance for marine sediments: Geo-Marine Letters, v. 10,

353 p. 37-44, https://doi.org/10.1007/BF02431020.

354 Tribovillard, N., Algeo, T.J., Lyons, T., and Riboulleau, A., 2006, Trace metals as

355 paleoredox and paleoproductivity proxies: An update: Chemical Geology, v. 232,

356 p. 12-32, https://doi.org/10.1016/j.chemgeo.2006.02.012.

357 Tyson, R.V., 2001, Sedimentation rate, dilution, preservation and total organic carbon:

358 Some results of a modelling study: Organic Geochemistry, v. 32, p. 333-339,

$359 \quad$ https://doi.org/10.1016/S0146-6380(00)00161-3.

360 Van Der Weijden, C.H., 2002, Pitfalls of normalization of marine geochemical data using

361 a common divisor: Marine Geology, v. 184, p. 167-187,

362 https://doi.org/10.1016/S0025-3227(01)00297-3. 
Publisher: GSA

Journal: GEOL: Geology

DOI:10.1130/G47150.1

363 Warning, B., and Brumsack, H.J., 2000, Trace metal signatures of eastern Mediterranean

364 sapropels: Palaeogeography, Palaeoclimatology, Palaeoecology, v. 158, p. 293-309,

365 https://doi.org/10.1016/S0031-0182(00)00055-9.

\section{FIGURE CAPTIONS}

367 Figure 1. Gamma ray (GR), sedimentation rate (SR), trace metal element (TME) ratios,

368 and authigenic fraction accumulation rates (AFAR) of Mo and Ni in the Upper Montney

369 and Doig Phosphate formations, western Canada. AFAR values are presented with

370 confidence interval accounting for $\pm 20 \%$ incertitude in SR. (A) Variation of TME proxies

371 and Mo and Ni AFAR across the Upper Montney-Doig Phosphate boundary. (B)

372 Variations of proxies within the Upper Montney Formation, considering high-resolution

373 SR changes across seven parasequences. In B, duration of each parasequence is estimated

374 to be 0.2 m.y. (Euzen et al., 2018). White dash lines represent moving average on five

375 samples.

378 Figure 2. Scatter plots of $\mathrm{V}$ versus $\mathrm{Ti}(\mathrm{A})$ and $\mathrm{Cu}$ versus $\mathrm{Ti}(\mathrm{B})$ in units 1 and 2 of the

379 Vaca-Muerta Formation (Argentina) from two wells. Uncorrected data are shown in

380 shades of gray, and corrected elementary concentrations are shown in shades of blue.

381 Here, source trends are identical between wells to reflect same nature of detrital material.

383 Figure 3. Influence of different sedimentation rates on concentration of authigenic

384 elements. (A) Conceptual basin where sediment supply at each margin is different. (B) 
Publisher: GSA

Journal: GEOL: Geology

DOI:10.1130/G47150.1

385 Variations in dilution of authigenic elements in two locations, each related to different

386 sediment supplies. OM—organic matter; SR—sedimentation rate. 